\title{
The Safe Harbour Issue and the Justifications for Crimes under the Penal Code of Somalia
}

\author{
Anton Girginov \\ ${ }^{*}$ Corresponding Author
Anton Girginov \\ Article History \\ Received: 10.07.2019 \\ Accepted: 22.07 .2019 \\ Published: 30.07 .2019
}

A former State Prosecutor and University Professor, PhD, DSc; International Prosecution Adviser in Mogadishu with European Union Capacity Building Mission in Somalia

\begin{abstract}
The International Maritime Organization encourages countries to offer assistance to vessels in distress. Before they take the decision, allcountries are expected to perform a risk assessment. They should not reject any refuge applications by distressed vessels before carrying it out. Often, the requested access to the place of refuge is also granted to vessels which constitute some potential thread. However, even if the shelter provision was based on a perfect risk calculation, severe undesired damages may exceptionally occur. Moreover, they may outweigh the values that were expected to be rescued. Such exceptional situations are not entirely ruled out, regretfully. They raise the issue of risk justification: as to whether it was reasonable or not to undertake the risk. This issue makes it necessary to clarify the general concept of risk. Refusals of admittance in cases of distress are not ruled out either. They may also raise questions about justifications in penal law. Mostly, such questions concern the state of necessity, when the distress has been caused intentionally and to make the costal authorities grant access to a targeted place of refuge. Under Article 36.1 of the Somali Penal Code, admittance shall be refused in this case. However, the author maintains the opposite solution; he argues that the Article should be modified, accordingly, as in most foreign countries.
\end{abstract}

Keywords: Distress, place of refuge, justified risk, state of necessity, deliberate creation

\section{INTRODUCTION}

Safe harbour is provided to distressed vessels. The International Maritime Organization adopted the "Guidelines on places of refuge for ships in need of assistance" [Resolution A. 949(23) of 5 December 2003] to encourage countries to offer assistance to vessels in distress. All countries are expected to perform a risk assessment. They should not reject any refuge applications by distressed vessels before carrying out such assessment of the individual situation. According to Item 3.12 and 13 of the Guidelines,

"When permission to access a place of refuge is requested, there is no obligation for the coastal State to grant it, but the coastal State should weigh all the factors and risks in a balanced manner and give shelter whenever reasonably possible. In the light of the outcome of the assessment provided for above, the coastal State should decide to allow or refuse admittance, coupled, where necessary, with practical requirements".

\section{SAFE HARBOUR AND THE RISK JUSTIFICATION}

Distressed vessels may apply for permissions to access a place of refuge. This is "a place, where a ship in need of assistance can take action to enable it to stabilize its condition and reduce the hazards to navigation and to protect human life and the environment" - Item 1.19 of the Guidelines. The place of refuge may include a port, a place of shelter near the coast, an inlet, a lee shore, a cove, a fjord or a bay or any part of the coast.

Often, the requested access to the place of refuge is granted [1]. However, even if the shelter was based on a perfect risk calculation, severe unexpecteddamages may exceptionally occur. Moreover, they may outweigh the values that were expected to be

\footnotetext{
${ }^{1}$ According to Article 27 [Assistance to vessels in danger], Paragraph 1 of the 1959 Somali Maritime Code "the Harbour Master, if aware of a vessel being in danger or of a shipwreck or other accident, must immediately provide assistance."
}

Copyright @ 2019: This is an open-access article distributed under the terms of the Creative Commons Attribution license which permits unrestricted use, distribution, and reproduction in any medium for non commercial use (NonCommercial, or CC-BY-NC) provided the original author and source are credited. 
rescued. Such exceptional situations are not entirely ruled out, regretfully. They raise the issue of risk justification: as to whether it was reasonable or not to undertake the risk. This issue makes it necessary to clarify the general concept of risk. Its general concept gives solutions to most of the problems relating to the different sorts of risk, including the risk inherent in granting safe harbour. This is why explanations follow about theprerequisites for risky acts and the necessary restrictions to their perpetration, in general, covering all kinds of risk: medical, economic, military, naval, cosmic, etc [2].

Nowadays, risky acts become both necessary and popular in all spheres of life. The risk issue has always been a challenge, but not many countries have produced a general legal framework for it. The countries, which already have, outline the risky act as a justification to offence in their Penal Codes after the state of necessity, usually. Penal law rules on justified risk, wherever they exist, are subsidiary to the legal framework for the state of necessity. Rules on necessity require success, whereas the problems of risk and its probable justification come in when the activity fails.

The Somali Penal Code $\{P C\}$ contains no rule of justified or reasonable Risk. In part, such a justification exists, for example, in Article 41 (3) of the Iraqi PC which outlines the so-called medical risk. Other countries have rules in their PC-s on the economic risk, e.g. Article 13a of the Bulgarian PC. The PC-s of third countries have provisions codifying all permissible or reasonable risks into a single justification, e.g. Article 41 of the Russian PC. Regardless of their peculiarities, different justified risks have common features which form the concept of justified (reasonable or permissible) risk. This justification might be considered for introduction in the Somali $\mathrm{PC}$ as well.

This risk has been expressly recognized as a separate justification in the eastern half of Europe, mostly. One can find this justification in Article 13a of the Bulgarian PC and Article 34 of the Lithuanian PC, Article 27 of the Polish PC, Article 41 of the Russian CC and Section 27 of the Slovak CC, etc.

These articles provide a positive $[3]$ legal framework for permissible risk. Until its legislative recognition, the risk was regulated by borrowing the rules on the state of necessity. As these rules represented favourable criminal law provisions, they were applicable by statutory analogy. This ANALOGIA LEGIS is not forbidden as in this case the provision applied is favourable to the actor. Therefore, criminal law is applicable in bonam partem\{Lat:: "in a good sense, with a positive connotation"\} and can never violate the "Nullum crimen, nulla poena sine lege" principle, in particular.

\section{THE ESSENCE OF RISK}

To take a risk means to stand the possibility of causing some undesired harm while in pursuit of some desired benefit. The undertaking of "risky" activities is generally encouraged in cases when the desired result could be socially useful. For example, society accepts the risk of speeding ambulances and fire engines to save life and property, but it does not accept a similar risk posed by a reckless motorist fleeing the police. Hence, when some risky act is under consideration, in deciding whether it is justifiable, its social purpose is of utmost importance $[1,10,12]$.

"Danger" and "risk" are not synonyms. Risk always involves some danger, but not any danger constitutes a risk. When it comes to risk, the accompanying danger is never wanted. It is solely a necessary condition that the actor must tolerate while attempting to achieve some desired result. Therefore, the risk is a combination of danger and opportunity to achieve the result[ $\left.{ }^{4}\right]$. This result shall be socially useful to make the justification of the act possible at all.

The risky act may end up with success. This happens when its overall balance is positive: the desired result has been achieved without any accompanying harm at all, or significantly smaller harm has accompanied it. In such situations, the act committed is socially useful, and the actor is likely to be granted some award only. Such risky acts are not relevant to criminal law, in general.

\footnotetext{
${ }^{2}$ Risk undertaking is not foreign even to criminal justice. For example, an accused person may, based on an agreement with the public prosecutor/ investigative judge, be used as the so-called co-operative witness. Thus, under Article 129 of the Iraqi Criminal Procedure Code [CPC] or Articles 298-303 of the CPC of Kosovo, the suspect may be granted immunity for giving testimony against the high level of the criminal organization in which $\mathrm{s} /$ he participates. However, s/he may not execute his/her part of the agreement and eventually, create difficulties to the investigators and prosecutors in charge, and even bring the criminal proceedings against the big criminal bosses to failure.

${ }^{3}$ Some laws mention justified risk, but they do not positively outline it. Instead, they directly deal with non-justified risks by solely referring to them as a basis to define recklessness, usually. Thus, recklessness is defined as the taking of unjustified risk, e.g. Article 15.05 (3) of the State of New York Criminal Code and Article 2.02 (2) (c) of the US Model Penal Code. However, the normal starting point is the risk, which is justified. The unjustified one, need to determine recklessness and knowledge, which comes per argumentum a contrario from the notion of justified risk. No one can safely figure out what unjustified risk is if the law does not tell what justified risk is. Therefore, legal provisions should clarify justified risk: its prerequisites and the boundaries of risky acts. If the actor does not meet the legal conditions of justified risky acts or, at least, if s/he oversteps its legal boundaries, his/her act becomes socially unacceptable and legally unlawful. Then his/her guilt would be possible, and it would be necessary for competent judicial bodies to look for its specific manifestation, incl. in the form of recklessness or indirect intent, in particular.
}

${ }^{4}$ The Chinese symbol (or character) of risk best captures this duality: 危險. 
Indeed, a risky act may be unsuccessful: the desired result has not been achieved at all, or though achieved, it has been accompanied by greater harm. Such situations of an overall negative balance require checks as to whether the risk was worth taking since it might have ended up in a failure. The production of the harm caused is generally prohibited by some provision of the PC, and it must be determined as to whether there are sufficient grounds to justify the performed risky act exceptionally.

Thus, risk alone is not sufficient to make the act a criminal law issue. For the relevance of the act to criminal law, it is also necessary that the created danger materializes by causing some loss. For example, a driver of a fire engine rushing to a fire is justified in exceeding the speed limit. Even with sirens wailing, the speeding engine may raise the danger of a traffic accident, but the risks of harm are higher if time is lost getting to the fire. In this situation, the driver's behaviour executes special permission for fire engines to take the risk of a traffic accident. The permission excludes the applicability of the general administrative restrictions regarding the speed. At this point, though, the driver's behaviour has not yet become any criminal law problem. It may become such a problem only if some severe harm occurs, e.g. the driver crashes into another car and cannot reach the burning building at all. These undesired consequences make the unsuccessful risky act fall under the legal description of some crime (e.g. damage or destruction of another person's property or economic mismanagement). Thus, given the harm it causes, the act corresponds to the criminal law prohibition, expressed by the legal description. Then only the act becomes a subject of interest to criminal justice. Hence, the act must otherwise constitute a crime, if it were not a risky one. As any other justification in criminal law, justified risk "simply reflects permission extended for whatever reason - to do what the criminal law otherwise forbids" [4].

However, not every unsuccessful risky act, irrespective of the amount of the harm caused, is an independent problem of criminal law. To constitute such a problem, the act shall not be expressly allowed by some general legal permission, such as "implementation of law", fulfilment of duty, or exercise of a right. Otherwise, if the act is allowed by any such provision, it would be justifiable under it. Hence, the actual need for the legal institution of justified risk comes in for those risky acts, which do not fall within the general justification of 'implementation of law' or any other general justification.

\section{THE CONDITIONS TO JUSTIFY RISK TAKING}

It would never be possible to entirely avoid the risk of failure and undesired harm in any sphere of life because it would mean to stop all expeditions, experiments, tests of new vehicles/technologies, investments, rescue operations. As almost all such activities pose some danger, it may follow that all of them shall be prohibited. However, this is not possible. On the contrary, in the name of the progress society has to tolerate certain dangers which accompany medical interventions, military operations, production of many goods, banking activities, etc. Nowadays, with the development of complex technologies, risk became a part of the human progress that plays an essential role in financing, banking, commerce, construction works, transport, science that requires investment, undercover operations by police and other law enforcement agencies, etc. In some situations, heavy losses occur, namely: deaths, serious injuries, destruction of property, financial losses. Inevitably, they will happen in the future. Nothing can entirely prevent them from occurring.

In situations when severe harm occurs, competent judicial bodies shall make sure that the risky act was justifiable. For this purpose, they must find the right answer to the question as to whether it was worth taking the risk in the given conditions. If the answer is a positive one as the risky act meets the requirements for its undertaking, this risk is qualified as justified (also: permissive/permitted, or allowed, or reasonable, or tolerated one). Such risk is unsuccessful but acceptable. However, where it was not worth taking the risk in the given conditions, then the fact that the risky act has been committed in the name of a socially useful result constitutes, most often, a mitigating circumstance only.

Even the worst result alone, although predictable in general when it comes to risk, cannot entail criminal responsibility for the actor, regardless of the peculiarities of his/her act that produced the result. To be criminally liable, s/he should also have acted in a way contrary to existing legal provisions.

The risky act is "legitimate" and does not entail criminal liability of the person who acts within its legal boundaries to satisfy the needs of the society and purposes of science and technology. As in the case with the previous justifications, the relevant conditions pertain to the state of justified risk and to the risky act itself.

\section{Conditions Relating to the State of Justified Risk}

a. First of all, the state of risk can exist if there is some serious social need which can be satisfied by achieving a specific result. There are two types of desired outcomes that may justify any risk, incl. the outcomes which conclude in failure. The first of them is to attain some significant positive change - knowledge, financial benefit, etc. through an expedition, experiment or investment, involving in any case possibility of loss. In such situations, the problem arises when and because society does not gain anything at all as the action results in inflicted losses only or it gains something but at the expense of significantly greater harm.

The other desired result that may justify a risk is to avoid some negative change - prevent damage from occurring through a rescue operation involving the possibility of losses. In such situations, the problem arises when and because the damage has not 
been prevented at all, as the action resulted in inflicted losses only and the necessity rules are not applicable, or the damage has been prevented but at the expense of more significant harm.

b. One is allowed to risk if there is no "non-risky" (not posing any danger) way to attain a socially useful objective that he wants. Thus, according to Article 42 (2) of the Ukrainian PC, "A risk shall be justified if the goal pursued could not, under the circumstances, be achieved otherwise than by an action (omission) involving risk..."5. In view of this requirement, justified risky act resembles necessious act as both are subsidiary in the aforementioned sense. In contrast to them, the private defence ${ }^{6}$ is not subsidiary since anyone is allowed to resort to it, even if he or the third person assaulted may run away.

c. The risk must be reasonable. It may be undertaken if it does not represent any pure adventure where the actor relies solely on luck to avoid failure demonstrating in this way insufficient concern for others.

The actor should be aware that some legal interests might be infringed, but he accepts this probability as his action is in pursuit of a socially useful goal. The risk should always make sense. The planned action must aim at a result which is sufficiently serious and/or very likely compared to the possible harm.

The risk taken must be reasonable following two general criteria: a qualitative - how much the value of the desired result exceeds the value of the possible harm; and a quantitative criterion - the probability of achieving the desired effect compared to the likelihood of causing more significant harm. Thus, according to Article 13a (2) of the Bulgarian PC, "In deciding the issue whether the risk was justified, taken into consideration must also be the correlation between the expected positive result and the eventual negative consequences, as well as the probability of their occurrence". Where the risk constitutes some experiment with a physical person involved as a potential victim, his/her informed consent (for the risk assumption) is required in advance under most criminal laws regulating risk.

It follows that, in contrast to the legal framework for necessity, risk law requires a comparison not only of the values of the two opposing results (the harms): the desired positive result and the negative result which actually occurred. Risk law also requires a comparison of the probabilities of their occurrence. Thus, the idea of the lesser evil, inherent in extreme necessity, is no longer a sufficient measure when it comes to justified (allowed) risk. The quantitative comparison between saved and sacrificed values is insufficient to judge whether the risky act is justified or not. If solely the value criterion of extreme necessity were valid, the risky act would always be justified when e.g. one buys a lottery ticket for 10 dollars to win 10000 dollars. However, once probabilities are also taken into account, the risky act may get the opposite evaluation, as the loss of the invested 10 dollars is inevitable (100\% probability) while the probability of the gain is insignificant (1\%, even less). Hence, this qualitative comparison between the probabilities of occurrence of the desired positive result and the undesired harm shall also be made to judge whether the risky act is socially beneficial justified or not.

Regardless of the insufficiency of the quantitative comparison between saved and sacrificed values, the general idea of proportionality stays as an objective characteristic of the risky act. The combination of the absolute value of the desired social result and the likelihood of its achievement must always exceed the combination of the absolute value of the harm suffered and the likelihood of its occurrence. The act would be "unjustifiable if the gravity of the foreseeable harm, multiplied by the probability of its occurrence, outweighs the foreseeable benefit from the conduct [3]".

d. Finally, the specific risky act may be undertaken if not expressly prohibited by law, e.g. experiments with some vulnerable persons. For exemple, Article 13a of the Bulgarian PC does not allow any risky act in the economy if it may cause death or bodily injury. Such act shall "not endanger the life and health of another".

\section{Conditions Relating to the Act in Justified Risk (the Risky Act)}

The leading peculiarity of the risky action is that it is not successful. This makes the risk different from and even contrary to the necessity justification. First of all, the risky act may be undertaken for attaining a positive change - a situation that has nothing to do with necessity and cannot, therefore, be governed by its rules. More importantly, the necessity rules always require success while the risk becomes a criminal law matter only when the risky action is unsuccessful.

However, the harm to the interests affected shall not occur through arrogant miscalculation. Besides, the actor should have exercised necessary care to avoid the negative result. To this end, Article 13a (1) of the Bulgarian PC requires that the actor should have taken all necessary measures to prevent the harm from occurring or to reduce its volume, at least.

\footnotetext{
${ }^{5}$ Likewise, Article 27 (1) of the Slovak PC stipulates that "An act, which otherwise gives rise to criminal liability, shall not be considered as a criminal offence if it is performed by a person who, in accordance with the latest knowledge and information, carries out socially beneficial activities ..., provided that it is not possible to obtain social benefit expected from the performance of such an act without taking the risk".

${ }^{6}$ It is often called self-defence, including defence of others and defence of property as well [Herring, 2011].
} 
Unlike the legal framework for necessitous acts and similarly to that for undercover activities (Article 12b of the Bulgarian PC), the legal provisions on risky acts do not always regulate them explicitly and in full. Some penal law institutions of justified risk have one or more blanket indications (elements) that are filled out by the specific rules for risky activities undertaken in the different areas of life. These rules are found in administrative laws and/or constitute some technological achievements which eventually, specify the requirements for the particular risky act. The legal description of allowed risk contains them in one blanket indication (element), at least, such as: "it is not counter to explicit ban established by a normative act, complies with the modern scientific and technical achievements and experience" - Article 13a of the Bulgarian PC7. Such rules complete, together with the legal description in the $\mathrm{PC}$, the necessary requirements to conclude that the risky act is justified.

The use of blanket indications makes the legal framework for risky acts, both stable and flexible. Thanks to their blanket nature, the indications take automatically into consideration any modification in bylaws regulating risky activities in different spheres of social life. Such blanket indications are indispensable. They give to bylaws, applicable to specific risky acts, the necessary legal power to preclude the applicability of the respective prohibitive provisions of the PC. Otherwise, the bylaws, though special, shall not be applied given their lower legal power. Hence, their applicability on the principle that lex specialis derogat lex generalis is not achievable without the empowering blanket indications in the legal description of justified risk in the PC.

The same approach to regulating risky acts might be applicable to risks undertaken in cases of a granted safe harbour, in particular. According to Item 3.2 of the Guidelines on places of refuge for ships in need of assistance, each country should establish own rules on risk assessment of situations when ships in need request access to a place of refuge. If the country's domestic law contemplates a legal description of justified risk which, expectedly, contains one or more blanket indications, they are likely to be filled out by the respective rules on the aforementioned risk assessment.

Finally, it is worth noting that European Union countries produce such rules on risk assessment based on the "EU Operational Guidelines on Places of Refuge" (Version 5 - Final 1 February 2018). The Operational Guidelines were prepared in a spirit of enhanced co-operation and coordination among all parties involved, including Member States' Authorities and concerned Industry. Recently, following maritime incidents involving ships in distress in waters outside the jurisdiction of any one State, the Member States of the European Union, together with the European Commission and the European Maritime Safety Agency, decided to review the framework for co-operation and co-ordination between States in such cases, to improve the existing arrangements. As a result, last year the latest version of the EU Guidelines (No. 5) was produced. Thereafter, as a matter of principle, each State involved in the response operation should examine their ability to provide a place of refuge.

\section{Safe harbour and the necessity justification}

Refusals of admittance in cases of distress are not ruled out either. They may also raise questions about justifications in penal law [7]. Mostly, such questions concern the state of necessity under Article 36.1 of the Somali PC when the distress has been caused intentionally aiming to make the costal authorities grant access to some place of refuge.

\section{Article 36.1 of the $P C$ reads as follows}

"Whoever has committed an act, having been compelled by the necessity of saving himself or others from actual danger of serious bodily injury, and where such danger has not been voluntarily caused by him or could not otherwise be avoided, shall not be punishable provided that the act is proportionate to the danger, and the person is not legally bound to expose himself to such danger".

\section{The source of danger and the actor's involvement}

According to the text of this provision, the conduct of the actor may be qualified as a necessitous act only if the danger "has not been voluntarily caused by him". Per argumentum a contrario, if the danger has been caused by him, the unlawfulness of his saving action shall not be precluded. It is unjustified and therefore, a prohibited action.

The Penal Codes of a limited number of foreign countries also contain such a 'no provocation' requirement. For example, Article 54 of the Italian PC and Article 25 of the PC of Bosnia and Herzegovina ${ }^{8}$ prescribe that the state of necessity shall not have been deliberately created by the actor to produce permission for him to cause the harm, which occurred, under the disguise of a rescue operation.

However, any such deliberate creation of the danger together with the causation of the necessary final harm by the same person is regarded as an intentional crime everywhere. It is a crime even in countries where the 'no provocation' requirement does not exist at all. Therefore, the non-compliance with this requirement is not needed to make a crime out of such person's conduct. It follows that the 'no provocation' requirement (if it exists at all), does not contribute in any way to the criminalization of the person's conduct.

\footnotetext{
${ }^{7}$ Similarly, Article 34 (2) of the Lithuanian PC stipulates that "The risk shall be deemed justifiable where the committed act is in line with the contemporary science and technology...". See also Article 27 (3) of the Polish PC and Section 27 (2) of the Slovak PC.

${ }^{8}$ Pursuant to Paragraph 2, "an act is committed out of necessity, if committed for the purpose of averting from himself or from another an immediate or direct and imminent and unprovoked danger that could not have been averted in any other way, provided that the harm resulting from such act did not exceed the harm threatened".
} 
Actually, this 'no provocation' requirement criminalizes solely the provoked necessitous act of the person by excluding it from the justification under Article 36.1. It follows that the unlawfulness of such an act is not precluded. Hence, any infliction of harm for averting the danger, which has been previously provoked by the same actor, is prohibited. If nevertheless, such a necessitous act is performed, it may be repelled as unlawful through the private defence under Article 34 of the Somali PC.

In this sense is also the provision of 3.2.2 \{Safe Harbor\} in CHAPTER 3, Protection of Persons and Property at Sea and Maritime Law Enforcement of the US Commander's Handbook on the Law of Naval Operations. The provision allows foreign ships in distress to enter safe harbours but only if the conditioning distress is "real and not contrived" [8]. Otherwise, if it has been contrived (deliberately created), the foreign ship is prohibited from entering the harbour. If the ship tries to enter, it might be stopped by force...

The problem, however, is that such dangers rarely affect only the persons who have deliberately created them to misuse the state of necessity. Usually, the danger affects third persons (solely or together with the creating person). Such third persons have never participated in the creation of the danger, let alone for the purpose of opening the way to producing the final detrimental result. In view of thereof, it makes no sense to disallow the protection of the third persons. If the captain of the ship causes distress, the passengers shall not suffer: he shall be authorized to save them by entering the harbour and punished afterwards for the illegal border crossing into the country.

Exceptionally, the actor may have created such a danger which affects him only. Again, however, it is difficult to argue that he shall be prohibited from protecting himself by excluding his necessitous act from the justification under Article 36.1 of the Somali PC. On the one hand, such exclusion may be counterproductive as it would further complicate the law on necessity. On the other hand, the civil law obligation, deriving from the situation, might be a sufficient deterrent. Because the actor was the intentional creator of the danger as well as the beneficiary of his own necessitous act for averting this danger, he shall pay the compensation to the victim of the final detrimental result as the one at the expense of which the endangered values of the actor were rescued[9]. This 'zero' benefit alone is likely to dissuade him from undertaking the whole operation.

Secondly, the necessitous act of the person, who provocatively created the conditioning situation, constitutes his positive post-criminal behaviour, actially. Contemporary penal law encourages such behaviour of offenders in the implementation of its growing preventive function. The necessitous act in question is such behaviour also; it is very similar to the voluntary withdrawal from attempt under Article 18.2 of the Somali PC. Moreover, the two post-criminal acts may even coincide as the voluntary withdrawal from attempt might be performed through a necessitous act as well. For example, late in the evening, the actor has given poison to a whole family they are likely to die in an hour or so. The only way to save them is to break into the nearest pharmacy shop and take medicine which would neutralize the given poison. Obviously, no one shall be allowed to stop the actor from saving the poisoned family in this only possible way.

Further on, since such a necessitous act, which constitutes a voluntary withdrawal, shall be allowed, there is no point in prohibiting other necessitous acts for the sole reason that they do not constitute any voluntary withdrawal. On the contrary, as the only peculiarity of their conditioning danger is the lack of the actor's desire to produce the respective derivative harm, this actor shall per argumentum a fortiori be allowed to prevent its occurrence.

Thirdly, the comparison of the provoked state of necessity with the actio in libera in causa (Latin: produced incapacity) under Article 49 of the PC also supports the conclusion that the necessitous act shall not be prohibited and repelled throughthe private defence. The two situations look very much alike. Both situations consist of two consecutive acts. The same actor performs them: the first act initiates a process leading to some harm while the second one materializes the existing danger by converting it into some actual harm.

However, when it comes to the actio in libera causa, the actor is held penally responsible only for his former act bringing himself to the situation of insanity/incapacity. He is not responsible for his latter act, although it is harmful as it does not save anything at all. This following act is unlawful and therefore, is an act which may be stopped through private defence. In contrast, the actor who provoked the state of necessity should not be stopped from performing his second act of saving the endangered value as this act is even socially useful. Because the criticized 'no provocation' requirement in Article 36.1 of the PC prompts the opposite conclusion (an unfounded one) its removal from the text is strongly recommended.

This legal requirement might be a source of confusion; it signifies a lousy understanding of the legal institution of necessity. It is counterproductive to require that the danger shall not have been created by the actor who averts it to protect the endangered

\footnotetext{
${ }^{9}$ It is worth clarifying that there will be no compensation at all in the opposite situation, when the averted danger was created by the victim (including through his object) rather than the actor, even if the actor himself benefited from hisrescue/necessitous act. Compensation is due only if the actor has turned the victim's object into a source of danger and to rescue his endangered values destroys it or something else not belonging to him. Thus, pursuant to Section 228 of the German Civil Code, no act of necessity, done to avert a danger by destroying the object of danger, constitutes a ground for compensation unless "the person acting in this manner caused the danger".
} 
interest. Even in such a case, he is authorized to protect the interest by causing necessary harm. As the actor saves this interest, his activity is socially useful and shall not be prevented through any private defence as 'unlawful conduct'. His rescue act is no less useful than similar acts by persons who have not caused the danger.

This does not mean, though, that in this situation, the actor does not commit any crime at all. The only problem is not to confuse his act of averting the danger with his previous criminal act of creating this danger and eventually resulting in the occurrence of some necessary harm. Obviously, he would be responsible for this previous act. The complication in the causal connection cannot preclude its criminality.

\section{Other essential requirements concerning the state of necessity}

According to the text of Article 36.1 of the Somali PC, the danger ... could not otherwise be avoided. The common interpretation, though, is that the danger could not be avoided in a harmless way. Therefore, it is not necessary that the way, to which the actor has the resorted, was the only possible way. If the requirement is understood in this way, it would mean that if two possibilities exist to avoid the likely harm by causing some smaller, they both eliminate each other. In view of thereof, if the aforementioned interpretation is acceptable, it would be better to modify the existing text into the following one: the danger ... could not be harmlessly avoided.

The text of Article 36.1 also requires "that the act is proportionate to the danger". Proportionality, however, is required for private defence as well. Because, traditionally, some difference between the two defensive acts exists, the peculiarity of the necessitous act must be clearly described in the text. Unlike the situation with the private defence where the proportionality concerns the opposing acts, here the proportionality relates to the results: caused and avoided. In contrast to private defence, it is not sufficient that the necessitous act is prevented from being strikingly disproportional to the assault. It is, most often, necessary that the harm caused is smaller than the harm avoided [2, 9]. It might be a positive step it this peculiarity of the boundary of the act is described in the text of Article 36.1 of the PC.

\section{CONCLUSIONS}

A place of refuge is a place where a ship in need of assistance can take action to enable it to stabilize its condition and reduce the hazards to navigation and to protect human life and the environment. Such ships are sources of danger. Their admission to the place of refuge involves significant risk. The risk undertaken should be reasonable following two general criteria: a qualitative how much the value of the desired result exceeds the value of the possible harm; and a quantitative criterion - the probability of achieving the desired effect compared to the likelihood of causing more significant harm.

A ship in distress shall not be refused access to a place of refuge solely on the grounds that the distress has been deliberately created with the aim to make the respective authorities grant entry. In general, the act of necessity should not be prohibited even if the danger has been voluntarily caused by the actor. Either way, this actor shall be held criminally responsible for the intentional causation of the final detrimental consequences.

\section{REFERENCES}

1. Ale, B.J.M. (2002). Risk Assessment Practices in the Netherlands. Safety Science, 40: 105 - 126;

2. Berman, M. N. (2005). Lesser evils and justification: A less close look. Law and Philosophy, 24(6), 681-709.

3. Dressler, J. (2005). Criminal Law, p. 15. Retrieved November 11, 2016 from: https://

Iscontent.westlaw.com/images/content/DresslerCrim Law. pdf;

4. Eser, A. (1976). Justification and Excuse, in "American Journal of Comparative Law", 24: 621-629.

5. Government of Hong Kong. (2002). Societal Risk Guidelines for AcceptableRisk Level. Retrieved February 18, 2018 from: http://www.info.gov.hk/planning/tech_doc/hkpsg/ english/ch12/ch12_fig3.htm;

6. Herring, J. (2011). Criminal Law, $7^{\text {th }}$ edition, Palgrave Macmillan, London, 290.

7. Robinson, P. H. (1975). A theory of justification: societal harm as a prerequisite for criminal liability. UCLA L. Rev., $23,266$.

8. US Navy, U.S. (2007). Marine Corp, US Coast Guard. The Commander's Handbook on the Law of Naval Operations, Edition July 2007, Washington, p. 56. Retrieved May 22, 2019 from: https://www.jag.navy.mil/documents/NWP_1-14M_Commanders_ Handbook.pdf;

9. Töngür, Ü., Hsu, S., \& Elveren, A. Y. (2015). Military expenditures and political regimes: Evidence from global data, 19632000. Economic Modelling, 44, 68-79.

10. Vrijling, J. H. K., Van Gelder, P. H., Goossens, L. H., Voortman, H. G., \& Pandey, M. D. (2004). A framework for risk criteria for critical infrastructures: fundamentals and case studies in the Netherlands. Journal of Risk Research, 7(6), 569-579.

11. WHAT IS RISK?, (2007), p.5. Retrieved April 21, 2019 from: http:// people.stern.nyu.edu/adamodar/pdfiles/valrisk/ch1.pdf;

12. Кузнецова, Н. Ф., \& Тяжкова, И. М. (2002). Курс уголовного права. Общая часть. Том 1: Учение о преступлении/под ред. НФ Кузнецовой, ИМ Тяжковой. 